\title{
Medievalista
}

Online

12 | 2012

Número 12

\section{As «Leis Jacobinas». Estudo e transcrição}

\section{Margarida Garcez Ventura}

\section{OpenEdition}

\section{Journals}

Edição electrónica

URL: http://journals.openedition.org/medievalista/636

DOI: 10.4000/medievalista.636

ISSN: 1646-740X

\section{Editora}

Instituto de Estudos Medievais - FCSH-UNL

\section{Edição impressa}

Data de publição: 1 Junho 2012

\section{Refêrencia eletrónica}

Margarida Garcez Ventura, «As «Leis Jacobinas». Estudo e transcrição », Medievalista [Online], 12 | 2012, posto online no dia 19 fevereiro 2014, consultado no dia 30 abril 2019. URL : http:// journals.openedition.org/medievalista/636 ; DOI : 10.4000/medievalista.636

(C) IEM 
Título: As «Leis Jacobinas». Estudo e transcrição

Autor(es): Margarida Garcez Ventura

Enquadramento Institucional: Faculdade de Letras de Lisboa / Academia Portuguesa da

História

Contacto: margaridagarcezventura@gmail.com

Fonte: Medievalista [Em linha]. №12, (Julho - Dezembro 2012). Dir. José Mattoso.

Lisboa: IEM.

Disponível em: http://www2.fcsh.unl.pt/iem/medievalista/

ISSN: 1646-740X

Data do artigo: Fevereiro, 2012.

\section{Resumo}

Como noutros reinos da cristandade, também o rei português, recorrendo tanto à fundamentação teológica como ao direito romano, considerava ser seu direito e dever exercer jurisdição sobre muitos casos que o clero tinha como exclusivamente seus. Apresentamos um breve comentário às chamadas "Leis Jacobinas" (Nov. 1418-Dez. 1419), simultaneamente testemunho e acelerador da polémica entre o poder régio e a Igreja nos finais da Idade Média. Publicamos também uma releitura de um dos treslados das "Leis Jacobinas".

Palavras-chave: Poder secular, relações Igreja-Estado, iberdades eclesiásticas, direito romano, Bártolo de Sassoferrato

\section{Abstract}

As in another realms of Christianity, also the portuguese king, using both the theological reasons as the roman law, considered his right and duty to exercise 
jurisdiction over many cases that the clergy had as exclusively theirs. Here is a brief comment on the so called "Leis Jacobinas" (Nov. 1418-Dec. 1419), simultaneously trigger and witness of the controversy between the Church and the royal power in the late Middle Age. We also publish a new reading on one of the transcriptions of these laws.

Keywords: Secular power, Church-State Relations; Ecclesiastical freedoms; roman law; Bartolo of Sassoferrato.

\section{As «Leis Jacobinas». Estudo e transcrição}

\section{Margarida Garcez Ventura}

A 19 de Dezembro de $1419^{1}$ o Doutor Diogo Martins publicitou perante todos os desembargadores, ouvidores e sobrejuizes de D. João I um conjunto de quarenta ordenações que logo foram designadas por "leis jacobinas",2 por serem da inspiração ou mesmo da autoria de Diogo Martins, isto é, Iacobus Martini.

Tendo em conta a relevância dessas leis, o concelho e homens bons de Lisboa pediram ao rei o respectivo treslado, o qual consta na carta testemunhável, datada de 24 de Agosto do ano seguinte, que agora publicamos. António Domingues de Sousa Costa

\footnotetext{
1 Adoptamos a data que consta do treslado que publicamos. António Domingues de Sousa Costa ("Leis atentatórias das liberdades eclesiásticas...") indica outros treslados com outra datação. Maria Helena da Cruz Coelho (D. João I, p. 212) propõe a data de 8 de Novembro de 1418 para a promulgação destas leis e a de 19 de Dezembro de 1419 para a sua publicitação no desembargo régio.

${ }^{2}$ COSTA, António Domingues de Sousa, o. c., p. 524.
} 
revelou a existência de outros treslados na Biblioteca Apostólica Vaticana, alguns contendo comentários dos ouvidores pontifícios João Gonçalves e João de Mela ${ }^{3}$.

É frequente que os incautos estudantes ${ }^{4}$ considerem a Idade Média como um tempo de total preponderância da Igreja, incluindo aí, também, a supremacia em questões de poder, isto é, de jurisdição concreta sobre os territórios, súbditos, capacidade de legislar, de vigiar ou de punir... se me é permitido lembrar Foucault.

Fixemo-nos nas questões da jurisdição da igreja na sua correlação com o poder temporal, chamando a atenção desde já para o facto de essa relação se ter alterado durante os longos mil anos da Idade Média. Assim, convém referir que o âmbito cronológico em que nos movemos é o dos finais do século XIV e o primeiro quartel do século XV em Portugal, e que os actores são, por um lado, o rei e seus legistas e, por outro, a clerezia nacional, o papa e a cúria romana, também com os seus juristas 5 .

Em Portugal, as relações entre o rei e o clero estiveram sempre longe de ser tranquilas. Não se erguiam, porém, conflitos de ordem teológica ou disciplinar, mas sim de ordem jurisdicional que resultavam da progressiva definição dos conteúdos do "ofício de rei".

O ofício de reinar exerce-se nas conjunturas concretas e em interacção com os outros poderes: da nobreza, da clerezia, dos oficiais régios, dos concelhos, dos povos em geral cuja voz se ouve em cortes e fora delas... Mas, quando se debate o porquê, o para quê e, sobretudo, o como do poder régio, tudo é remetido para os membros do clero: súbditos do rei mas presença máxima da Igreja, essa instituição que, na terra e por mandato de Cristo, é a dispensadora do poder. Na verdade, se, como escreveu São Paulo em frase repetida até à exaustão na Idade Média, não há poder que não venha de Deus, é a Igreja que o dispensa, ou controla, ou permite ou vigia... conforme se acolha uma das muitas formulações a este respeito. Tudo isto nos territórios do poder temporal sobre fiéis

\footnotetext{
${ }^{3}$ Vd. n. 27.

${ }^{4}$ Este trabalho destinava-se a uma colectânea de estudos jurídicos medievais portugueses a ser publicada no Brasil e dirigida a estudantes. Mantivemos o seu carácter didáctico.

${ }^{5}$ Vejam-se, entre outros, VENTURA, Margarida Garcez, Igreja e poder..., pp. 32-38, "O ofício de rei no Portugal quatrocentista...", e "D. Duarte", pp. 502s.
} 
leigos súbditos do rei ou sobre matérias de índole económica ou financeira. As querelas sobre as liberdades eclesiásticas resultam desta imbricação de poderes.

$\mathrm{Na}$ Idade Média chamava-se libertas ecclesiastica ao conjunto de imunidades e prerrogativas da Igreja. Tais isenções tinham como finalidade permitir que membros do clero tivessem condições de vida que lhes permitissem, sem preocupações, dedicar-se à oração e à administração dos sacramentos, isso é, ao serviço de Deus a tempo inteiro. Por isso toda a restrição sobre pessoas, bens e locais da Igreja seria considerada um atentado contra o serviço de Deus. Deixemos, porém, as enumerações gerais para nos aproximarmos, ainda que de forma breve, das condições vividas em Portugal nos finais do século XIV e começos do século XV.

D. João I sobe ao poder na sequência da crise aberta pela morte de seu irmão D. Fernando ${ }^{6}$. O então mestre de Avis é um entre outros candidatos ao trono, porventura aquele que estava mais afastado de uma solução estritamente legitimista. Para além da mobilização de alguma nobreza, cidadãos ou vizinhos de cidades e vilas e de outras muitas pessoas ou grupos referidos por Fernão Lopes na sua Crónica de D. João I - e não consideramos de somenos surtos de adesão com laivos de messianismo - foi, porém, nas cortes de Coimbra de 1385 que D. João se tornou rei ${ }^{7}$. Aí João das Regras, doutor em leis na universidade de Bolonha ${ }^{8}$ e discípulo de Bártolo, aplicou os princípios do direito romano no sentido de demonstrar que, estando vago o trono pelas razões que aduziu, caberia ao povo a escolha de um novo rei. Mas, para além do direito, o jurista esclarece o critério a que deveria obedecer o voto dos povos: que o eleito teria de ser de boa linhagem, corajoso na defesa do reino, amigo do povo, bom, devoto e disposto a permanecer ao lado do verdadeiro papa - o papa de Roma - contra os hereges e cismáticos castelhanos, adeptos do papa de Avinhão. O discurso de João das Regras produziu efeito, se é que a eleição não estava já assegurada.

\footnotetext{
${ }^{6}$ COELHO, Maria Helena da Cruz, o. c., pp. 32s; VENTURA, Margarida Garcez, O Messias..., pp. 9s e Igreja e poder... pp. 78s e 95s e e "Lisboa, a cidade do Messias...".

${ }^{7}$ LOPES, Fernão, Crónica del Rei Dom Joham I..., Caps. CLXXXII-CXCII.

${ }^{8}$ HOMEM, Armando Luís de Carvalho, O Desembargo..., p. 157.
} 
Mas os apoios pagam-se, se nos permitem a crueza da linguagem. E não só o apoio da nobreza, do clero e dos concelhos nessas cortes, mas ainda durante os largos anos de guerra contra Castela.

Importa pois destacar a relação entre D. João I e o clero, uma relação de cooperação visível nas cortes de Coimbra, prolongada pelos tempos de guerra que se seguem em algo tão objectivo como a participação em acções bélicas e na utilização dos dinheiros de seus benefícios para financiar campanhas militares. É certo que, na época, o facto de os castelhanos serem cismáticos parece atenuar estes comportamentos irregulares. O envolvimento activo na guerra, assim como a aplicação de proventos eclesiásticos nesses projectos eram contra as determinações do direito canónico, pelo que, logo após 1411, encontramos inúmeras súplicas ao papa para que lhes conceda a absolvição.

A consolidação do mestre de Avis no trono de Portugal faz-se também através de prelados fiéis ao papa de Roma, Urbano VI. Bastará percorrer os nomes dos detentores dos cargos episcopais e de prelazia ${ }^{9}$ para vermos fiéis ao mestre, por vezes seus familiares, que são também chamados a representar o reino nos concílios de Pisa e de Constança, tendo alguns deles ocupado altos cargos na burocracia régia, pois eram doutores em leis pelo estudo de Bolonha ou de Pádua.

Na verdade, irão confundir-se a fidelidade a D. João e ao papa de Roma. Para usar a expressão registada por Fernão Lopes, o evangelho português ${ }^{10}$ que o Mestre (equiparado ao Filho de Deus) mandou pregar a D. Nuno ${ }^{11}$ (equiparado a São Pedro) e à sua gente (os apóstolos) era que todos acreditassem firmemente que o papa Urbano era o verdadeiro pastor da Igreja e que deveriam defender o reino com os seus bens e com a própria vida.

\footnotetext{
${ }^{9}$ COSTA, António Domingues de Sousa, o c., pp. 519-521.

10 Expressão registada ou forjada pelo cronista inspirado no "evangelho eterno" das concepções joaquimitas, tão presentes na construção da narrativa dos primeiros anos da nova dinastia. LOPES, Fernão, o c., Cap. CLIX.

${ }^{11}$ Não queremos deixar de assinalar que o processo de canonização de D. Nuno Álvares Pereira, iniciado na cúria romana por D. Duarte logo após a sua morte, foi levado a cabo e o seu exemplo de santidade proclamado em Roma, a 26 de Abril deste ano de 2009. Insistiu-se aí sobretudo no seu despojamento pois, ingressando na ordem do Carmo em 1423, vai dedicar-se ao serviço dos mais necessitados, à oração e à penitência. Mas convém lembrar, também, as suas virtudes enquanto senhor leigo e as virtudes em tempo de guerra. Vd. VENTURA, Margarida Garcez, "Uma lâmpada...".
} 
Todavia, a indecisão na definição das esferas do temporal e do espiritual, comum a toda a Idade Média, tal como se converte em cooperação entre o rei e o clero ou em protecção mútua, assim muito facilmente resulta em abusos e em gravíssimos conflitos. No caso que agora importa podemos dizer que o ponto de viragem se dá após a assinatura das tréguas com Castela, que se realizou em Ayllon a 31 de Outubro de 1411.

É claro que existiram, já no reinado de D. João I, alguns conflitos antes dessa data, por exemplo, no que dizia respeito à salvaguarda dos bens de igrejas e mosteiros ameaçados por leigos poderosos, aos quais o novo rei também tinha de ceder. Mas eram querelas geradas por casos pontuais, não por um plano sistematizado, nem na legislação, nem na prática, como sucede com as "leis jacobinas". Ordenações essas que, se é certo, como ficou registado, que respondem a dúvidas e a situações particulares, irão provocar, como ordenações régias que são, um enorme impacto em todo o reino e, porventura, em situações até então pacíficas.

Voltemos então às tréguas de 1411. Livre dos encargos da guerra com os castelhanos e ressarcidos os povos das sequelas da guerra, D. João I pode direccionar o combate contra quem sempre quisera combater: os muçulmanos. A sequência não é nossa, mas de Zurara ${ }^{12}$, que nos indica também o direccionamento inicial do projecto (Granada), as razões da opção por Ceuta e todo o debate teológico suscitado por D. João I a propósito da licitude da conquista. Passemos ao lado deste assunto, fixando somente que D. João I tratou de assegurar desde logo a sua posição como guarda avançada da cristandade contra o avanço do Turco, primeiro junto do clero nacional e, depois, solicitando ao papa a bula de cruzada.

Para se dedicar totalmente à condução global do projecto de Ceuta, o rei conferira aos infantes D. Pedro e D. Henrique as tarefas do recrutamento de homens e do provimento de navios, delegando em D. Duarte, herdeiro do trono, as áreas da justiça e da fazenda ${ }^{13}$. O infante D. Duarte iniciou essas funções na primavera de 1413, no contexto da preparação da expedição, mas nunca mais foi delas dispensado: muito pelo contrário, a sua intervenção é cada vez mais visível, mesmo, ou sobretudo, em pontos-chave da

\footnotetext{
${ }^{12}$ ZURARA, Gomes Eannes de, Crónica da Tomada de Ceuta..., Caps. I - XI.

${ }^{13}$ Segundo o próprio D. Duarte no Cap. XIX do seu Leal Conselheiro, texto sem dúvida usado por Zurara na supracitada Crónica.
} 
governação. Por isso são indubitavelmente da sua responsabilidade todas as situações que emergem da leitura das Leis Jacobinas, assim como a intencionalidade destas ordenações.

Como se verá, o texto das leis refere algumas situações concretas no âmbito da justiça, nomeadamente relacionadas com o comportamento de corregedores e juizes. Ora, o infante publicara em 1418 um novo Regimento dos Corregedores ${ }^{14}$, notável pela sua novidade e abrangência. Este regimento e as leis jacobinas terão se ser considerados por nós como o foram na época, isto é, fazendo parte de uma estratégia concertada para a definição do efectivo poder régio na sua mais problemática fronteira.

Trata-se, pois, de uma nova inflexão no governo do reino fundamentada numa concepção do ofício de reinar que, não sendo nova, usa vigorosamente a convicção de que o poder régio deverá exercer-se sobre todos os súbditos, sobre todo o território, e sobre todos os assuntos, indubitavelmente sobre pessoas leigas e sobre questões relacionadas com aspectos patrimoniais e económicos em geral. Uma concepção de poder que encontramos explícita ou implícita nos escritos de D. Duarte e do infante D. Pedro, e que vive tanto da utilização do direito romano como da reivindicação de uma sacralidade régia da qual a conquista de Ceuta fora a confirmação ${ }^{15}$.

Ceuta foi a primeira praça do norte de África a ser reconquistada aos muçulmanos, retomada por cristãos sucessores de Roma... Foi D. João I que logrou essa conquista, mau grado as pretensões castelhanas que vinham desde o tempo de Afonso X, o Sábio ${ }^{16}$. Os dividendos de política externa e perante o papa foram logo reivindicados no concílio de Constança, que reuniria no ano seguinte. Na sessão de 5 de Junho de 1416, um dos embaixadores de D. João I proferiu um discurso, o qual incluía a notícia da conquista que afirmou ser uma "vitória que deve trazer grande alegria e júbilo a toda a Igreja". A importância geoestratégica (a questão religiosa está, na Idade Média, incluída neste conceito) de Ceuta justificou a expedição e justificará todos os sacrifícios em gente e em

\footnotetext{
${ }^{14}$ DUARTE, Luís Miguel, D. Duarte, pp. 65s.

${ }^{15}$ NASCIMENTO, Aires Augusto Nascimento, "Estratégia diplomática...", passim.

${ }^{16}$ VENTURA, Margarida Garcez, "Portugal e Castela...", pp. 132s.
} 
dinheiro. Dos continuados anos de grande esforço militar lembremos somente que o cerco de 1418-1419 obrigará a gastos acrescidos. Havia que buscar financiamento, também, junto do clero nacional, através de terças decimais e outras contribuições reclamadas pelo rei ou melhor, pelo infante D. Duarte enquanto encarregue da fazenda régia.

Convém que nos detenhamos sobre o Doutor Diogo Martins, autor destas leis que proclamam eloquentemente a sua matriz romanista ${ }^{17}$. Diogo Martins é um discípulo da célebre universidade de Bolonha, onde se licenciou a 30 de Maio de 1401 e se doutorou a 18 de Março de 1402. Entre 1407 e 1430 será desembargador de D. João I. Uma longa carreira de serviço, de que dão testemunho as cento e cinquenta e seis cartas régias que subscreve em parceria com outros desembargadores. Para além desta normal actividade, foi nomeado embaixador ao concílio de Pisa em Maio de 1409, juntamente com o Doutor Lançarote Esteves, Mestre Frei João Xira, Mestre Lourenço Afonso, o bispo de Lamego e o arcebispo de Lisboa. Depois do concílio, já em 1410, aparece designado como “cavaleiro". Mas a marca do Doutor Diogo Martins são as quarenta leis por si publicadas e por certo redigidas sob a sua orientação, quando não da sua autoria, como ficou dito. Como se verá mais em pormenor, essas ordenações enformam um momento de enorme acutilância nas relações entre o rei e o clero no medievo português.

Algumas das leis jacobinas surgem como que suscitadas por situações que teriam sido colocadas às justiças régias, como se pode ler no texto, ou mesmo em cortes, onde os representantes do povo reclamam contra abusos de jurisdição por parte dos prelados ${ }^{18}$. Paro o conteúdo de outras, o autor recorre à anterioridade das disposições legislativas como forma de as justificar. Num processo muito comum à mentalidade medieval, a novidade está sob suspeita: declara-se que os reis anteriores já teriam legislado de forma semelhante $^{19}$. De facto, não faltaram concórdias firmadas entre os reis de Portugal e o episcopado, algumas das quais receberam a aprovação do papa, tomando, por isso, o

\footnotetext{
${ }^{17}$ HOMEM, Armando Luís de Carvalho, o c., pp. 290-291; COSTA, António Domingues de Sousa, o c., pp. 524-525.

${ }_{18}$ Podemos referir, nas cortes de 1390-91, o cap. 6; nas de 1406, o cap. 3; nas de 1408, o cap. 10; nas de 1410, o cap. 24; nas de 1418, os caps. 5 e 17. Vd. SOUSA, Armindo de, As Cortes..., Vol. II, passim.

${ }^{19}$ Nas $8^{\mathrm{a}}, 9^{\mathrm{a}}, 16^{\mathrm{a}}, 22^{\mathrm{a}}, 27^{\mathrm{a}}, 28^{\mathrm{a}}$ e $36^{\mathrm{a}}$ leis.
} 
nome de concordatas ${ }^{20}$. Porém a grande referência é D. Dinis ${ }^{21}$. É muito instrutivo para nós percebermos a lógica da interpretação do Doutor Diogo Martins a respeito de este ou daquele artigo das concordatas dionisianas ou de ordenações deste mesmo rei relativas ao clero. Trata-se de facto de clarificações surpreendentes, e tanto mais quanto os documentos de D. Dinis irão ser, na cúria romana, objecto de oposta interpretação.

Retomando, pois, as ordenações dionisianas - por vezes pouco claras, defensivas e escassamente implementadas - as leis jacobinas manifestam, como já referimos, uma concepção de "ofício régio" que entra em colisão com as tradicionais prerrogativas do clero e que, claramente, trazem a marca do infante D. Duarte. De notar, ainda, o cuidado em frisar que as decisões legislativas foram tomadas consultando os doutores em leis e no âmbito do desembargo régio (as $23^{\mathrm{a}}, 25^{\mathrm{a}}$ e $29^{\mathrm{a}}$, entre outras), onde, note-se também, já não existem clérigos.

A redacção das leis é suficientemente clara para dispensar grandes explicações, pelo que nos limitamos a acentuar alguns comportamentos legislativos que surgem de forma recorrente em muitos acordos entre o rei e a clerezia. Vejamos então alguns desses temas, sem grandes preocupações de sistematização ou de inventário completo ${ }^{22}$.

Uma das indubitáveis intenções destas leis é marcar o direito à presença do rei, isto é, de tabeliães régios, em todas as circunstâncias, mesmo em casos de jurisdição eclesiástica $\left(1^{a}\right)$. Paralelamente, nota-se a exigência da entrega às justiças régias de todas as querelas, denúncias e escrituras em geral, mesmo de processos da competência eclesiástica $\left(5^{\mathrm{a}}, 14^{\mathrm{a}}\right)$. Essa tentativa de omnipresença vê-se também quando se ordena

${ }^{20}$ Vd. A. Leite, “Concordatas”, in Dicionário de História Religiosa..., Vol. 1, pp. 423-429.

${ }^{21} \mathrm{O}$ A. refere-se insistentemente à concordata chamada dos "40 artigos" assinada em Roma a 12 de Fevereiro de 1289 (Ordenações del-Rei Dom Duarte, pp. 227-246 e Ordenações Afonsinas, Liv. II, Tít. 1). O legislador refere ainda os casos legislados por D. Dinis sobre clérigos sob jurisdição régia e leigos sob jurisdição eclesiástica (Ordenações del-Rei Dom Duarte, pp. 270-277).

VENTURA, Margarida Garcez, "Um novo conceito de Estado...".

${ }^{22}$ VENTURA, Margarida Garcez, Poder régio..., Vol. II, Quadro I (Esferas de conflito). Aí se podem encontrar os assuntos sistematizados com a referência a acordos anteriores e posteriores (de D. Dinis a 1455). 
que as justiças civis ${ }^{23}$ tomem conta dos casos em que há suspeita de que o juiz eclesiástico é negligente $\left(2^{\mathrm{a}}\right)$.

Outra grande linha de força é aquela que considera todas as questões relativas aos bens temporais como sujeitas à jurisdição civil, mesmo que sejam praticadas por clérigos. É por aí que estes podem ser chamados ao foro secular, com inúmeras ocasiões de especificação $\left(3^{\mathrm{a}}, 18^{\mathrm{a}}\right)$.

Mas não só os clérigos que lidam com bens materiais, sejam eles terras ou mercadorias, devem responder civilmente $\left(3^{\mathrm{a}}, 18^{\mathrm{a}}\right)$. A exigência de foro secular estende, por outra via, aos moradores da casa real $\left(22^{\mathrm{a}}, 36^{\mathrm{a}}\right)$ e professores na universidade $\left(37^{\mathrm{a}}\right)$, assim como aos clérigos dissolutos, como os goliardos e jograis $\left(31^{\mathrm{a}}\right)$. Ou ainda quando o réu é leigo, como afirma o direito romano, o juiz deve seguir o foro do réu $\left(4^{\mathrm{a}}, 20^{\mathrm{a}}, 25^{\mathrm{a}}\right)$.

Notáveis também são as consequências jurisdicionais retiradas da condição laical: os leigos devem, por norma, responder em tribunal civil em todas as questões que não sejam espirituais. A excepção aberta para os rendeiros das terras das igrejas e mosteiros cessa com o contrato, sendo aplicada pena de prisão e multa para os que ousarem o contrário $\left(26^{\mathrm{a}}\right)$. Paralelamente, define-se o campo espiritual no sentido restritivo. $\mathrm{O}$ espiritual não abrange, por exemplo, questões de dotes ou arras matrimoniais, fuga de mulheres aos maridos, responsabilidade na criação dos filhos... $\left(10^{\mathrm{a}}, 11^{\mathrm{a}} 20^{\mathrm{a}}, 38^{\mathrm{a}}\right)$. Também aqui a legislação é severa, ameaçando os leigos que, nestes casos, recorram a tribunal eclesiásticos, com prisão e multas. É por essa via que o rei reserva veementemente para si tudo o que se relacione com injúrias cometidas contra judeus ou mouros convertidos ao cristianismo, assim como o castigo daqueles que depois voltem à antiga fé $\left(24^{\mathrm{a}}, 40^{\mathrm{a}}\right)$.

Destaquemos a constatação de muitos clérigos de ordens maiores ou menores que o são para fugir à justiça régia $\left(23^{\mathrm{a}}, 33^{\mathrm{a}}\right)$, o que implica desconfiança e vigilância. De facto, há que saber se os que se dizem clérigos realmente o são, através do controle do traje, da tonsura e das letras apostólicas que exibem $\left(8^{\mathrm{a}}, 35^{\mathrm{a}}\right)$.

${ }^{23}$ O conceito "civil" pode parecer anacronismo quando trabalhamos no século XV, mas note-se que Diogo Martins o usa $\left(22^{\mathrm{a}}, 25^{\mathrm{a}}\right)$ como bom romanista e discípulo de Baldo $\left(21^{\mathrm{a}}\right)$. 
É porque desconfia da licitude das razões de alguns eclesiásticos, que o rei vai actuar sobre questões tão graves como a excomunhão, não através da recusa da aplicação das consequências temporais dela, mas querendo ter a certeza de que os leigos estarão bem excomungados $\left(9^{\mathrm{a}}, 17^{\mathrm{a}}\right)$.

Finalmente, uma chamada de atenção para o beneplácito ${ }^{24}\left(28^{\mathrm{a}}\right)$. De facto esta instituição não é novidade, mas é-o a explicitação da sua justificação: poderiam vir da cúria romana e de instituições religiosas cartas contra o bem do reino. O legislador declara que só a passagem pela chancelaria régia poderia assegurar a legitimidade de tais diplomas. $\mathrm{O}$ castigo é severo para qualquer que ignore a ordem régia e publique tais cartas: pena de morte e confisco de bens.

Como é óbvio, as leis jacobinas suscitaram muitas querelas, das quais D. Duarte estaria informado pela dupla via das suas responsabilidades na justiça e na fazenda do reino. Assim, em 1423, o infante manda fazer um "ajuntamento" dos prelados e procuradores da clerezia de Lisboa, mas recusa ouvir as queixas e manda-os regressar a casa sem qualquer resposta ${ }^{25}$.

A partir de então, por iniciativa do arcebispo de Braga, o clero inicia o processo de recurso para Roma, através de dois enviados: João Vasques e Rui Dias, cónego de Braga e ex colector apostólico em Portugal. É este último que leva a João Vasques a carta, datada de Agosto ou Setembro de 1425, que acompanha as leis jacobinas, assim como uma lista de dezassete agravos ${ }^{26}$ perpetrados sobre o clero pelo rei seus oficiais.

Entretanto, o ambiente na cúria papal, influenciado pelas posições de alguns padres conciliares, não era favorável às pretensões dos reis em geral no plano da apropriação de direitos eclesiásticos. Exemplo disso é a recusa dada em 1423 ao cavaleiro Pedro Lobo, enviado por D. Duarte para pedir as terças eclesiásticas, e que regressa a Portugal sem nada ter conseguido.

\footnotetext{
${ }^{24}$ VENTURA, Margarida Garcez, "Elementos para a compreensão...".

${ }^{25}$ COSTA, António Domingues de Sousa, o c., p. 506.

${ }^{26}$ Resumidos por COSTA, António Domingues de Sousa, o c., pp. 536-537. Sobre o impacto das leis jacobinas no posicionamento do clero face ao poder régio vd. PINA, Maria Isabel Castro, Os Lóios..., pp. 54 s.
} 
Voltemos a João Vasques, encarregue de apresentar a Martinho V a referida carta de Agosto-Setembro de 1425, com o auxílio dos cardeais de S. Marcos e de Veneza, assim como de dois portugueses residentes na cúria, o Doutor Vasco Rodrigues e seu irmão o Doutor Afonso Rodrigues Garcia. Em carta enviada ao cabido de Braga, João Vasques dá conta de todas as diligências efectuadas, nomeadamente que fizera todos os possíveis para falar com o Doutor João de Mela, o mais famoso doutor que há na corte de Roma, pedindo-lhe que visse a lista de agravos e as ordenações.

João Vasques foi bem sucedido. Efectivamente, não só João Mela, mas também João Gonçalves, outro célebre ouvidor apostólico, vão comentar as leis jacobinas ${ }^{27}$. Tal como as citações abonatórias que encontramos junto de alguns capítulos no treslado de Lisboa, os comentários dos juristas papais estão baseados no direito canónico e civil, embora em muito maior número, pormenor e erudição.

O conflito agudizado em Portugal pelas leis jacobinas, assim como o seu eco na cúria de Roma, tem também de ser entendido à luz da grave crise da Igreja, nomeadamente nos conflitos entre os partidários da autoridade do papa sobre o concílio e os conciliaristas, crise bem viva no concílio de Pavia-Sena, encerrado pelo papa na primavera de 1424 . O assunto está pouco estudado e não é aqui o local para o fazer. Bastará lembrar dois factos: o primeiro, é que neste concílio os conciliaristas afirmavam o seu direito à deposição do papa sempre que ele consentisse na alienação dos bens eclesiásticos; o segundo, que João Gonçalves era conciliarista declarado, assim como, muito provavelmente, João de Mela. Deste modo os violentos comentários que produzem têm de ser entendidos nas mais amplas concepções sobre a Igreja e o modo de realizar a respectiva reforma. Por outro lado, a montante das propostas para essa reforma estava sempre uma determinada concepção dos objectivos fundamentais (e fundacionais...) da Igreja e, consequentemente, das suas reivindicações jurisdicionais.

\footnotetext{
${ }^{27}$ COSTA, António Domingues de Sousa, o c., pp. 525 e 531. Nos começos dos anos 90 o próprio Sousa Costa teve a amabilidade de me entregar em fotocópia a transcrição de um dos treslados com anotações destes ouvidores pontifícios. Sabemos que o trabalho estava bastante adiantado, mas o Autor morreu em 24 de Dezembro de 2002 sem o ter efectuado. Supomos que o manuscrito se encontra no seu espólio guardado no Seminário da Luz (Lisboa).
} 
Quaisquer que tenham sido as movimentações de João Vasques e dos outros portugueses residentes na cúria, das quais se conhecem resultados esparsos ${ }^{28}$, assim como as dos referidos ouvidores apostólicos, o facto é que Martinho V, a 28 de Abril de 1426, escreve as letras apostólicas Non sine magna admiratione ${ }^{29}$ dirigidas aos arcebispos de Braga e de Lisboa e seus sufragâneos e a D. João I. Depois de lembrar que o rei metia foice em seara alheia (ponere falcem suam in messem Ecclesie) quando se intrometia nas coisas da igreja, aponta a intervenção das justiças seculares sobre os clérigos e no controle das letras apostólicas através do beneplácito régio. O papa exorta os prelados a reunirem-se com os respectivos cabidos de forma a defender a liberdade da Igreja.

Obedecendo ao mandato papal, logo o bispo do Porto, D. Antão Martins, congregou no paço episcopal, a 23 de Setembro desse ano, vários abades e quase todos os párocos da sua diocese. Foi lida a bula papal, assim como um carta do arcebispo de Braga. Nesta carta D. Fernando da Guerra convocava o bispo do Porto para uma reunião que iria ter lugar em Coimbra ou em Braga a 30 de Novembro. Foram então eleitos os procuradores para esse encontro, que acabou por se realizar em Braga entre os dias 15 e 23 de Dezembro.

Nesta reunião, também conhecida por sínodo de D. Fernando da Guerra, os prelados irão debater todos as questões de que já se tinham queixado ao papa, as leis jacobinas e outros agravos entretanto constatados. Conhecem-se as actas da reunião, que inclui também registo de casos particulares ocorridos nas dioceses de Braga, Porto, Guarda, Lamego e $\mathrm{Viseu}^{30}$. Os compromissos assumidos prometiam firme luta pelo que entendiam ser a liberdade da Igreja, com previsão de longo pleito na cúria romana ${ }^{31}$.

Mas, se os prelados eram fiéis às liberdades da Igreja, eram também "criaturas" do rei, seus amigos e por vezes seus parentes. É bem possível que o próprio arcebispo de Braga

\footnotetext{
${ }^{28}$ De referir ainda uma resposta papal a uma súplica do clero bracarense relativa as opressões sofridas por igrejas e mosteiros por ocasião do falecimento dos seus prelados, datada de 15 de Março de 1424 (António Domingues de Sousa Costa, o c., p.552).

${ }^{29}$ Publicada por António Domingues de Sousa Costa, o c., Doc. II.

${ }^{30}$ Actas enviadas à cúria pontifícia, cujo original está na Biblioteca Pública de Évora existindo pelo menos duas cópias em Braga e trad. em latim na Biblioteca Apostólica Vaticana. Vd. Margarida Garcez Ventura, Poder régio e liberdades eclesiásticas...., Vol. II, Doc. 4.

${ }^{31}$ MARQUES, José, A Arquidiocese..., p. 80.
} 
tenha diligenciado no sentido da concórdia. O facto é que a 27 de Agosto de 1427 já os prelados haviam escrito a Martinho $\mathrm{V}$, após conversações com o monarca. Nessa carta pedem dispensa para não tratar judicialmente dos agravos contra as liberdades eclesiásticas, pois o rei havia-lhes prometido emendar alguns agravos, embora estes fossem já praticados pelos seus antecessores e, escrevem, o procedimento do rei ser defensável em algumas ocasiões: tudo para o "bem de sua patria e Reinos", segundo palavras de D. João $\mathrm{I}^{32}$.

O acordo era necessário e estava eminente, sendo conseguido na concórdia assinada em Santarém, a 30 de Agosto $^{33}$. Os artigos que serão objecto da concórdia são os que saíram da reunião bracarense, embora tivessem sido retiradas algumas reivindicações, queixas e linguagem mais acintosa. Os clérigos apresentaram-nos assim a D. João I: "Estes som os agravos que aa vosa mercee praz veer que som feitos em vosa terra aa Igreja e pesoas ecclesiasticas per vos e vosas justiças e pesoas seculares de voso senhorio os quaees prellados e clerezia vosos oradores som theudos de vo-los dizer e mostrar por bem de vosa alma e conciencia cujo carrego teem e das suas dellas". D. Duarte esteve presente em todo o processo, quer nas conversações prévias, quer nas respostas dadas a cada um dos artigos.

Como dissemos, os temas de conflito são recorrentes e continuam após a concórdia de 1427, surgindo em inúmeros processos registados nos Livros de Chancelaria. E, logo no reinado de D. Duarte, se renovam as queixas ao papa. Voltemos, porém, aos tempos mais próximos das leis jacobinas.

Os comentários dos ouvidores apostólicos João de Mela e João Gonçalves eram conhecidos em Portugal antes da referida carta de Agosto-Setembro de 1425, e por certo que tiveram o seu peso na concórdia de 1427, a qual, em alguns pontos, consigna também um recuo relativamente às posições extremadas das leis jacobinas. É certo que o relacionamento entre o rei e o clero é feito mais de "amigáveis composições" do que de querelas, ou talvez de ajustamentos após situações de potencial conflito. Por isso,

\footnotetext{
32 A carta-súplica dos bispos portugueses a Martinho V (Santarém, 27 de Agosto de 1427), publ. por COSTA, António Domingues de Sousa, o c., Doc. VII.

${ }^{33}$ Ordenações Afonsinas, Liv. 2, Tít. 7. Segundo SOUSA, Armindo de (As Cortes Medievais...., Vol. I, p. 343) a concórdia poderia ter sido produzida, não em Santarém a 20 de Agosto, mas nas cortes de Lisboa realizadas nesse ano.
} 
não é de somenos, em termos de consequência, o que escreveu João de Mela no prólogo ao seu comentário ${ }^{34}$. Recorrendo à autoridade de Justiniano, lembra que as leis iníquas devem ser rejeitadas pelos súbditos e pela Igreja, pois não têm força de lei natural, que deve ser honesta, justa e possível, útil e conveniente, conforme aos costumes, lugares e tempos. Portanto, os súbditos não devem obediência às leis injustas ${ }^{35}$. E continua, dizendo que as leis contra as liberdades eclesiásticas não poderão ser acatadas. Era conhecida em Portugal a fundamentação da desobediência às leis injustas e tal apelo vindo da cúria romana não poderia deixar de ser perturbador. Enfim, João de Mela afirmava ainda que o rei tinha incorrido em excomunhão por ter publicado tais leis.

Depois de tudo isto cabe perguntar qual seria a posição de D. Duarte a respeito do pomo da discórdia que eram as liberdades eclesiásticas. Podemos adiantar que ele as considerava como coisa a acreditar e a respeitar... mas punha em causa a sua formulação concreta. No capítulo 35 do seu Leal Conselheiro ${ }^{36}$., D. Duarte enumera cinco "cousas da nossa crença" nas quais a Igreja nos manda acreditar. A primeira é os dois Credos (o dos Apóstolos e o chamado de Santo Atanásio), a segunda é os sete sacramentos; a terceira é as virtudes; a quarta é o conhecimento dos pecados; a quinta é as liberdades e jurisdição da Igreja. Veja-se como este tema está colocado entre aquilo em que os fiéis devem acreditar para alcançarem a salvação eterna, o que não é dizer pouco. Vejamos o texto: "A quynta maneira he dos dereitos sobre as liberdades e jurdiçom da Igreja. E porquanto algũus destes som scriptos per letrados, que sobr'ello secreverom forom clerigos, e quyserom largamente favorezar a ssua parte, posto que o fezessem com boa teençom. Porem, esto nom embargando, todollos senhores em esta parte teem certas ordenanças em suas terras por conservaçom de seus estados e bem de sseus subdictos per antigo custume aprovadas que parecem contrairas a openyom delles, as quaaes entendo que cada hũu pryncipe deve guardar por serviço de nosso senhor deos como

\footnotetext{
${ }^{34}$ António Domingues de Sousa Costa, o c., pp. 562s.

35 Álvaro Pais em Speculum Regum e Status et Planctus Ecclesiae afirma que o cumprimento da lei injusta não só não obriga o súbdito como deve ser por ele repudiado. As leis justas dos reis são as que estiverem de acordo com a lei natural e divina. A fazer fé em Fernão Lopes, João das Regras teria referido isto para justificar a não obediência ao rei de Castela e a D. Beatriz. Vd. ALBUQUERQUE, Martim de e ALBUQUERQUE, Ruy de, História do Direito Português, I Vol. pp. 113 e 123-125.

${ }^{36}$ Como se sabe, o Leal Conselheiro é constituído por textos que vão sendo escritos ao longo de uma vintena de anos (c. 1415-c.1437), aos quais o rei, a pedido de sua esposa, vai dar alguma unidade e sequência. Não há nenhum elemento neste capítulo que nos dê uma data aproximada do trecho que agora nos importa, mas por certo será contemporâneo ou posterior a 1419.
} 
fezerom seus antecessors, segundo el com seu consselho por melhor acordar. Ca sam Paulo dyz hũa autoridade que os prellados, clerigos e religiosos muyto bem devem consiirar, ainda que a todos pertença. Manda em sua epistola que sejamos assy como lyvres, e nom que ajamos veeo de liberdade de mallicia. E com tal cubertura os senhores nom se devem estender pera britar o pryvylegio clerical mais que seus antecessores, nem dar lugar a eles que vyvam em desenfreado atrevymento, como algũus qur boos nom som fariam, se per os senhores nom fossem temperados, o que sempre se deve fazer com tento e boo conselho, com reguardo do serviço de deos”. D. Duarte habitounos a verificar como ele passa de formulações inicialmente de índole teórica ou mesmo teológica para comentários saídos das suas preocupações na governança do reino. Está tudo neste pequeno excerto: diz que a enumeração das liberdades foi feita por letrados clérigos os quais, ainda que com boa intenção, favorecem o seu status; que sempre os reis promulgaram leis que parecem contrárias à opinião desses clérigos, mas que são para o bem do estado real e para o bem dos súbditos; que essas leis devem ser guardadas por serviço de Deus como o fizeram os reis que o antecederam, de acordo com a sua vontade e consultados os seus conselheiros. Finalmente, recorre a São Paulo para expor como deve ser o equilíbrio entre a intervenção dos reis e o laxismo que permite aos maus clérigos comportarem-se sem qualquer castigo.

De facto, a todos os argumentos do fortalecimento do poder régio em todas as frentes e por todos os meios aduzidos pelos romanistas ao serviço do rei, a todos os argumentos que lhe eram conferidos pela origem divina do seu poder e pelo inegável favorecimento divino a D. João I (as vitórias sobre castelhanos e mouros faziam prova), se acrescenta a desconfiança de D. Duarte em relação a alguns clérigos e, consequentemente, a urgência de vigilância e de coacção com vista ao serviço de Deus e bem dos súbditos.

Veja-se como D. Duarte coloca em sequência a questão do conteúdo das liberdades eclesiásticas e esta proclamação do seu dever de correcção sobre os maus clérigos. Esses clérigos são aqueles que se deixam vencer pela tibieza e que aspiram a "riquezas, honras, reverências, liberdades", isenção da justiça secular ou do serviço na guerra - a parte agradável do seu estado - mas fogem da oração, dos serviços divinos, do ensino e do cuidado pelos outros, da administração dos sacramentos, dando mau exemplo com o 
escândalo da sua má vida. E. Duarte continua: "contra os quais diz Santo Agostinho que se querem alegrar com os santos, e as tribulações não querem suportar com eles"37.

Dissemos que as relações entre o rei e o clero no Portugal medieval não foram isentas de conflitos, e é certo, como, aliás, sucedeu por toda a cristandade ${ }^{38}$. Todavia, daquilo que ficou escrito não podem também outros incautos deduzir constantes conflitos. As leis jacobinas são um entre muitos episódios de um tema tão caro aos estudiosos do pensamento político: a tensão e o ajuste entre a autoridade espiritual e o poder temporal. Desse processo sairá a possível definição de fronteiras entre ambos, característica dos estados modernos do ocidente.

\section{LEIS JACOBINAS TEXTO}

Notas de edição

Como acima ficou dito, transcreve-se aqui a carta testemunhável contendo as leis jacobinas, recolhida no Livro I de Cortes existente no Arquivo Histórico Municipal de Lisboa. Este documento constitui um caderno com autonomia dentro do Livro, composto por seis fólios em pergaminho medindo $385 \times 285 \mathrm{~mm}$. O pergaminho é de boa qualidade, como convinha para tão importante conteúdo. Todo o documento está em muito bom estado, não apresentando lacunas de suporte ou qualquer mancha relevante.

Da responsabilidade de Vasco Esteves, bacharel em leis e chanceler-mor ${ }^{39}$, a carta testemunhável foi executada pelo escrivão em caligrafia cursiva bem regular, aparentada aos cursivos franceses ("lettre bâtarde") e à qual Eduardo Borges Nunes chama "letra joanina" 40 . A caligrafia, se não solene, é bem cuidada, com recurso a capitulares destacadas com aditamentos cursivos. A mancha do texto está bem distribuída na página e os capítulos encontram-se bem destacados.

\footnotetext{
${ }^{37}$ Leal Conselheiro..., Cap. IV, pp. 44-45.

${ }^{38}$ Citemos o caso próximo de Castela, estudado por NIETO SORIA, José Manuel, Iglesia ...

${ }^{39}$ HOMEM, Armando Luís de Carvalho, O Desembargo Régio..., p. 386.

${ }^{40}$ NUNES, Eduardo, Album de Paleografia Portuguesa, Vol. I, 1969, p. 12. O A. coloca a hipótese de esta moda de escrita ter chegado a Portugal no séquito francês (aquitânico) de D. Filipa de Lencastre.
} 
São devidos alguns esclarecimentos sobre os critérios de transcrição adoptados. Usamos as regras enunciadas por Eduardo Borges Nunes na sua edição das Ordenações del-Rei Dom Duarte, com algumas excepções de modo a conferir maior clareza ao texto, destinado prioritariamente aos alunos: modernização da pontuação e do uso das maiúsculas e minúsculas, actualização das funções dos "u" e "v" e dos "i" e “j”, assim como do uso da cedilha, eliminação das consoantes duplas iniciais, introdução de apóstrofos para substituir as elisões de grafemas, eliminação de repetições, correcção de pequenos erros de escrita e introdução, entre parêntesis rectos, do número de ordem dos parágrafos.

A sequência da numeração dos fólios do treslado em presença não corresponde à sequência da numeração das leis ${ }^{41}$, pelo que aplicamos a ordem pela qual surgem nos códices da Biblioteca Apostólica Vaticana. De notar que este treslado não contém as $1^{\text {a }}$, $2^{\mathrm{a}}, 3^{\mathrm{a}}$ e $4^{\mathrm{a}}$ leis. Recorremos, por isso, ao respectivo resumo feito por Sousa Costa ${ }^{42}$.

[O A. escreve segundo o anterior acordo ortográfico]

\section{0, Agosto, 14, Treslado das Leis Jacobinas pedido pelo concelho de Lisboa}

A. H. C. M. L., Livro I de Cortes, Doc. 19, fls. 93-98v.

Publicado parcialmente em Documentos do Arquivo Histórico da Câmara Municipal de Lisboa, Livros de Reis, I, Lisboa, 1957, pp. 204, 205; publicado na íntegra em VENTURA, Margarida Garcez Ventura, Poder régio..., Vol. II, Doc. 1.

[1 $1^{a}$ " A primeira lei estabelece a obrigação de os prelados terem notários régios nas causas de sua competência."

\footnotetext{
${ }^{41}$ No treslado de Lisboa é a seguinte a sequência das leis: no fl. 93 , da $5^{\mathrm{a}}$ à $8^{\mathrm{a}}$ (parte); no fl. $93 \mathrm{v}$, da $8^{\mathrm{a}}$ (parte) à $12^{\mathrm{a}}$; no fl. 94 , da $37^{\mathrm{a}}$ à $40^{\mathrm{a}}$ (parte); no fl. $94 \mathrm{v}$, a $40^{\mathrm{a}}$ (parte); no fl. 95 . da $13^{\mathrm{a}}$ à $15^{\mathrm{a}}$ (parte); no fl. 95v, da $15^{\mathrm{a}}$ (parte) à $18^{\mathrm{a}}$ (parte); no fl. 96 , da $18^{\mathrm{a}}$ (parte) à $20^{\mathrm{a}}$; no fl. $96 \mathrm{v}$, da $21^{\mathrm{a}}$ à $24^{\mathrm{a}}$ (parte); no fl. 97, da $24^{\mathrm{a}}$ (parte) à $27^{\mathrm{a}}$ (parte); no fl. $97 \mathrm{v}$, da $27^{\mathrm{a}}$ (parte) à 29 (parte); no fl. 98 , da $29^{\mathrm{a}}$ (parte) à $33^{\mathrm{a}}$ (parte), no fl. $98 \mathrm{v}$, da $33^{\mathrm{a}}$ (parte) à $36^{\mathrm{a}}$.

${ }^{42}$ COSTA, António Domingues de Sousa, o c., p. 526.
} 
[2] "A segunda dá normas para a solução de dúvidas sobre a competência dos tribunais, em reunião conjunta de ambas as justiças, secular e eclesiástica. No caso de negligência, deverá decidir a causa e executar a sentença o juiz cumpridor das prescrições, mesmo que se venha a provar a competência da outra jurisdição, civil ou eclesiástica”.

[3 $3^{a}$ "A terceira ordena que as querelas entre clérigos e leigos sobre bens patrimoniais, adquiridos por herança, e outras sobre bens, depositados ou em penhor, sejam julgadas pelos juizes régios visto tratar-se de bens temporais."

[4] "A quarta, baseada em leis anteriores, declara os juizes seculares competentes nas causas movidas por clérigos contra leigos, por motivo de injúrias reais ou verbais, visto o autor dever seguir o foro do réu."

[5 $5^{\mathrm{a}}$ Item. Achamos e nos he dito per nosos subditos que, quando alguum he demandado perante os prelados ou seus vigairos e elles entendem que nom devem de responder perante elles e veen-sse aos nossos juizes queixar por esto, e os nossos juizes, por saberem sse pertencem a elles conhocerem de taaes feitos ou nom envyam aos vigairos dos prelados que lhes dem os procesos, os quaees lhe dam em reposta que lhos nom darom mas que lhe darom os trellados, o quall he gram despesa e custo dos ditos nossos subditos. De mais, poderia acontecer que o feito sera tornado aos vigairos. Porem foi acordado per nos por bem da nossa juridiçom e esso mesmo por bem dos nossos subditos que, se taaes feitos ou procesos forem demandados onde estever a nossa Cassa, que entam lhes sejam dados os oreginaaes dos procesos. E se for fora da nossa Cassa, entam lhes sera dado o trellado da querella que a parte pedir ou demandar pera sua proll.

[6 $\left.6^{\mathrm{a}}\right]$ Item. Achamos e nos he dito que os nossos subditos demandam alguuns clerigos ou os clerigos demamdam os nossos subditos per qualquer parte que seja. E he dada sentença contra o clerigo que pague ou entrege aquella coussa por que he (?) demamdado ou por as custas. E quando vaaom perante os vigairos que executem as ditas sentenças, elles dizem que nom acham em que as executem. E por esto ficam as sentenças por executar e os nossos subditos ficam perdidosos. E porque nos achamos que qundo alguum beneficiado tem algumas 
rendas de seus beneficios que lhe deve seer tomada parte d aquella renda pera seer entregue aquelle por que foi dada a sentença. Poren foi per nos acordado que quando the nom forem achados os ditos beens que os vigairos dos prellados devem de executar as ditas sentenças em parte das rendas dos seus beneficios. $\mathrm{E}$ ahinda nos he dito que quando as ditas sentenças sam dadas contra elles que eles escondem os beens de guissa que se nom podem dar a execuçom. Porem nos achamos em dereito que elles devem de proceder contra eles a escomunhõees e a outros autos per que as ditas sentenças ajam execuçom.

[7 $7^{a}$ Item. Nos he dito que quando alguum feito que seja civel de que alguum clerigo saiba parte e el he requerido per nossos subditos pera testemunhar em el, o clerigo diz que nom testemunhara sem lecença de seu mayor. E porque nos achamos que el em tal caso deve testemunhar, vigairos dos prelados lhe devem dar lugar pera testemunhar, sem embargo nenhuum.

[8 $8^{a}$ Outrossi nos achamos uma ley nos livros das lex dos reis que ente nos forom, a qual fez el rey Dom Denis, na quall manda que qualquer que for acusado, posto que seja clerigo de hordeens mayores, que seja avudo como os outros leigos, asi nos feitos civis como nos crimes. E porque nos feitos crimes era duvidoso como avya de respomder, nos achamos em hordenamento e assy (fl. 93v) o husamos ataa ora que qualquer clerigo casado que fezer alguum malaficio nom andando em avito e em tansura ao tenpo do malaficio ou ao tenpo da prisom, que tal como esto lhe da nossa juridiçom e nos devemos delle de conhocer. E assi teemos mandado a todollos nosos juizes e justiças que o façam comprir e guardar.

[9 $9^{\text {a }}$ Item. Achamos nos livros dos reis que ente nos forom e foy pellos prellados pedido em cortes que alguuns, asy clerigos como leigos, se taaes andassem escomungados e nom quisessem sair das scomunhões que fosem presos per as nossas justiças e levasem delles as penas come de scomungados, scilicet, cada nove dias sesenta soldos da moeda antiga, do dia que forem scomungados ataa que sayam da dia scomunhom. E nos, porque o assi achamos e os reis d'ante nos sempre o fezerom, e ahinda mais que os douctores dos canones teem que asi se 
deve de fazer, por tanto mamdamos aos nossos alcaides e a todallas nossas justiças que asi o façom comprir e aguardar.

$\left[10^{\mathrm{a}}\right]$ Item. Achamos e nos foi dito per nossos sobrejuizes e desembargadores que quando alguuns casam e se prometem dotes ou arras ou sobrepartiçoões em algumas demamdas e veem asi a demandar algumas das ditas cousas, demandam-nos perante os vigairos dos prellados e seus ouvidores, nom perteencendo a elles a jurdiçom, e que os ditos vigairos the conhocem delo. As quaes cousas sam contra a nossa juridiçom, porquanto em taaes casos se nom trauta de casamento nem de cousa spiritual. Porem foy per nos acordado que os ditos feitos devem seer remetidos aos nosos juizes porque em taaes casos a nos perteence a juridiçom.

$\left[11^{\mathrm{a}}\right]$ Item. Nos he dito que alguumas vezes acontece que alguma molher fogue a seu marido e se vay pera casa de seu padre ou de seus parentes ou pera outro lugar que seu marido a nom pode aver, nom negando ella que nom he sua molher nem elle he seu marido. E alguuns taaes per comselho e enduzimento vaaom aos vigairos dos prellados que lhes dem carta per que lhe seja entregue, conhocendo do feito que aa justiça eclesiastica nom perteence, mas a nos. Porem foi per nos acordado que em taaes casos perteence a nos a juridiçom e os nosos juizes devem em taaes casos de conhocer.

$\left[12^{\mathrm{a}}\right] \mathrm{O}$ capitullo que foi feito em cortes com o Ifante meu filho, presentes os prellados e os procuradores dos prellados que hi nom veerom, o qual he que paguasem duzentas e conquoenta livras por hma livra, nos lhe mandamos requerer já aos ditos prelados que nom levasem mais que as ditas duzentas e cinquoenta liras por huma.

Estes doze capitollos ${ }^{43}$ que de suso sam scriptos forom publicados aos arcebispos e bispos e prellados destes regnos, que em taaes casos como estes

${ }^{43}$ Como se verifica, temos o treslado com oito capítulos e não doze, o que permite afirmar que se perdeu o registo dos quatro primeiros. 
nom tomase nenhuum conhocimento per que a nossa juridiçom fosse usurpada. E esto se pos aqui pera o depois os ditos prellados nom dizerem qu'esto lhe nom fora requerido nem sabyam delle parte.

(fl. 95) $\left[13^{\mathrm{a}}\right]$ Huum capitullo he que quando acontecer que alguum clerigo he presso por alguum malaficio que faça que se tenha tal hordem: que se for achado que he clerigo beneficiado ou de hordeens sagras, este tal mandamos que seja logo entregue ao vigairo. E se for clerigo de hordeens mayores (sic) este tal, ora seja casado, ora seja solteiro, posto que seja achado em avito e sem tansura, este tal mamdamos que nom seja entregue ataa que certamente seja achado que he clerigo. E esto se faça em na nossa casa. Mas se for perante os juizes ou corregedores, mamdamos que nom seja entregue ataa que a apellaçom venha aa nossa corte e hi seer vista se he clerigo ou nom. E esto se faz porque muito ameudo acontece que mostram cartas falsas per que mostram seer clerigos e elles nom o sam. Propter consuetudinem per quam aequirirur in hoc. Jurisdicio ut in c. cim conti de foro compe. ${ }^{44}$

$\left[14^{\mathrm{a}}\right]$ Outro capitulo he, que quando alguum creligo, asi de hordeens sagras como d'hordeens mayores acontece que he presso per seu prellado e o prellado pede que as nossas justiças lhe deem os trellados das querellas $E$ denunciaçõeenns e inquiriçõoes, nos mamdamos que sse tenha tal temperamento: que quando for per os nossos juizes e corregedores achado certamente que taaes sam creligos d'hordeens sagras ou beneficiados ou forem clerigos d'hordens mayores que já fossem entregues per nos ou nossas justiças, taaes como estes mandamos que sejam logo envyadas as querellas e denunciaçoões e inquiriçoôes do que a eles perteence, nom poendo em ellas os nomes das outras pesoas que nos ditos malaficios som culpados. Mas se acontecer que as nossas justiças forem requeridas que dem as ditas querellas e inquiriçoões dos clerigos solteiros ou casados d'hordeens mayores, mandamos

\footnotetext{
44 Transcrevemos em itálico a fundamentação encontrada no direito canónico e civil e em opiniões de juristas e de comentadores de ambos os direitos. Cita também as concórdias entre D. Dinis e o clero e outras leis dionisianas. São escritas pela mesma mão do texto principal.
} 
que os juizes e os corregedores as nom dem sem apellaçom, salvo quando for achado en na casa nossa que elles som clerigos e da jurdiçom eclesiastica. Porem muy muitas vezes he achado que eles nom sam clerigos e fazem esto a cautella por saberem quaaes sam as provas. E muytas vezes acontece que sobornam as testemunhas e alegam outras falsas defesas, per que as nossas justiças quando tal cousa fezessem e lhos entregassem nom poderiam fazer dereito daquelles que asi fossem culpados.

[15 $]$ Nos mandamos que qualquer molher que for barregaâ de creligo seja presa. E por a primeira vez seja presa e pague mil e quinhentas livras desta moeda que ora corre da cadea, ou doutra moeda se se esta mudar, comtanto que seja o preço desta, e seja degredada por huum anno da cidade ou villa com preguam na audiencia. E por a segunda vez seja degredada com preguam por huum anno fora de todo o bispado e pague a pena dos dinheiros. E por a terceira vez seja açoutada pubricamente com preguam per essa cidade, villa ou lugar. E porque era duvida quando alguma molher era (fl. $95 \mathrm{v})$ tomada ou pressa fora de casa do dito clerigo hindo aa fonte ou a outra parte, porem mandamos que os alcaides as nom prendam, salvo quando forem achadas em casa do dito clerigo ou em outra cassa sospita soo com soo. E esto façam os alcaides quando o souberem per testemunhas certas ou per taaes indicios que queiram parecer prova. Item mandamos aos alcaides e as nossas justiças que nom vaaom a casa dos clerigos pera as prenderem, salvo quando ouverem certa prova ou tal fama que os creligos as teem dentro de cassa como dito he.

$\left[16^{\mathrm{a}}\right]$ Achado he que os reis que ante nos forom esteverom sempre em posse que quando alguum homem morria e fazia seu testamento leixava que se fezessem por sua alma cousas que nom fossem certas, asy como misas, cantar ou proves vestir, ou remir rativos, que nom fossem de nome ou de numero certamente, que, se os testamenteiros nom compriam o testamento ataa anno e dia, que era avudo. E os reis os faziam destribuir por as almas dos finados em algumas outras obras piadosas. Porem mamdamos aos nossos desembargados (sic) que quando taaes feitos veerem, que asy o façam desembargar. L. id. quod pauperibus C. de epis. Et cie et vide ibi glo. Magistram et in i. L. Legatum fl. De administr. Rex et civi partin. 
$\left[17^{\mathrm{a}}\right]$ Antre nos e os bispos e prellados da nossa terra se acontece algumas vezes que eles poem sentença d'escomunhom em algumas pessoas, assy clerigos e outros leigos que sam da nossa juridiçom e alguuns delles nos dizem que aquella scomunhom que lhe he feita nom he feita a dereito e nos pedem por mercee que lhes demos carta para as nossas justiças que os nom prendam por esto, nem levem deles penas como de scomunguados. Nos mandamos aos nossos desembargadores que as cartas que ouverem de dar que as dem em este casos, convem a saber: quando, se alguma pesoa, ora seja eclesiastica ora seja sagral, se mostrar que esta apellada segundo se acustuma. Assi de futuro gravamine come em outras apelaçoões em que soem de dar cartas que mantenham os apellantes ataa que o artigoo da apellaçom seja desembargado per hu deve. E nom embargando esto, os bispos poem em elles sentenças d'escomunhom. Mandamos que em taaes casos os nom prendam nem evitem como escomunguados nem levem delles penas come d'escomungados e os mantenham em posse. E asi mamdamos aos nossos desembargadores que as dem em os outros casos em que as sempre custumarom de dar. Facit capitulum cum contin. Extra de fo. compe.

$\left[18^{\mathrm{a}}\right]$ E esso medes as contendas os clerigos com os almotaçaaes que sam postos per nosso hordenamento para elles e para todos em comunal, asi os clerigos como os leigos, em os mantiimentos asy como calçaduras e ferragens e outras cousas semelhantes, porque esta cousa he iguall a todos. E asy (fl. 96) achamos sempre de custume que em taaees feitos d'almotaçarias, pois que dello querem gouvir, que eles devem de responder perante os nossos almotaçaaees porque esto nom tangue crime nem coussa que seja spitituall. Facit l. regis dionisii et c. Cum contingat de foro compe. Quia per consuetudine acquiritur juridcio.

$\left[19^{\mathrm{a}}\right]$ Item mandamos aas nossas justiças que, se acontecer que alguum clerigo de querella d'alguum leigo, as nossas justiças nom recebam querellas nenhumas, a menos que nom dem fianças taaes per que o leigo possa aver seu corregimento se achado for que se lhe deve de dar, que doutra guisa seria mui grande mal seer querellado d'alguum leigo per que jouvesse em cadea ou longo tempo em demamda e nom lhe seer feita a enmenda. Articulus. 
$\left[20^{\mathrm{a}}\right]$ Duvyda foi ante nos que se huma madre tem alguum filho e o padre the nom quer dar criaçom se o demamdaria perante as nossas justiças se perante as justiças ecclesiasticas. E foi achado que o conhocimento dello perteence a nos e que as nossas justiças devem de conhocer de taaes feitos com'estes, porque o padre e madre e esso medes o filho sam leigos. E por esto mandamos aos nossos juizes e corregedores que quando tal criaçom for demamdada que conhoçam delo e nom a remetam aa juridiçpm eclesiastica. E porem poemos por ley e mandamos que nenhuma pesoa que seja sagral que nom seja ousado nem ousada de demandar denhuma criaçom perante a justiça eclesiastica, senom perante a nossa justiça. E quallquer que o fezer mandamos que seja pressa e nom solta sem nosso mamdado. E mamdamos que aa qual a acusar que lhe pague triinta coroas ou o preço que entam valerem. E porque ante os do nosso conselho veo huma duvida que se huum clerigo ou frade ouvesse alguum filho ou filha d'alguma molher ou outra pesoa que demandar alimentos, se a molher lhe demandaria a dita criaçom perante as justiças nossas ou perante os juizes eclesiasticos. E foy determinado que em tal caso perante os juizes ecclesiasticos deve de seer demandado, porque em tal caso o autor deve de seguir o foro do reeo. E em tal caso como este damos lugar aas molheres que em taaes casos como estes se nom entenda a dita ley por que mamdamos que quando esto acontecer que as nom prendam nem ajam a dita pena da ley suso scripta. Vide [...] in materia alimentorum 1. prima et per totum C. ubi pupillus educari debet et notatur perbar in tarione 1. ticia f. soluto matri quia auctor debet sequi foro rei vulgaria sunt jura 1. quod autor de proba.

(fl. 96v) $\left[21^{\mathrm{a}}\right]$ Achamos que se o clerigo de hordees mayores tam bem solteiro come casado se for chamado por testemunha perante as nossas justiças sobre algum feito e diser em ello falsso testemunho, que per tal falso testemunho se pode seer penado perante as nossas justiças civilmente. E assi mandamos aas nosas justiças que quando tal caso aveer que, nom embargando as hordees que tenham, que os possam penar como dicto he civilmente. Bald. In 1. prima C. quomodo et quando Ju. Angelusin repeticione 1. si vacancia de bo. na. Bar. et butri. et. cy in 1 . nullum c. de testi. 
$\left[22^{\mathrm{a}}\right]$ Achado he que husado foy na casa dos reis que ante nos forom e nos asi o husamos ataa ora que, se alguum clerigo fosse morador ou andasse com alguuns moradores de nosa casa e fezessem alguuns malaficios, asi como aver alguma moça de virgindade ou for demandado por alguum malaficio outro civillmente, e o caso fosse tal que logo diviadamente se podesse castigar, mandaos que o corregedor da corte possa sello conhecer, porquanto por serr com nossos moradores ou viverem com elles a nos perteence o castigamento deles. Artigoo he et consuetunine prorrogatur juridicio ut in C. cum contin. de foro compe. cum concordanciis ibidem.

$\left[23^{\mathrm{a}}\right]$ Acontece muitas vezes que alguum homem seendo sagral que matou outro homem ou fez outro malaficio per que a dereito deve de morrer ou perder alguum nenbro. E se foy fazer frade ou clerigo d'ordees sagras ou menores por escapar de nom aver a pena que per dereito deve d'aver. E porque esta coussa pareceo a nos que aquel que se metya frade ou fazia clerigo nom o fazia senom tam soolamente por scapar aa pena a que já era obrigado e nom por outra vontade d'aver aquella hordem, porem achamos com os douctores e outros do nosso Desembargo, fundando-se em razom e em dereito, asy como já 1. butri. dy. et co (?) que qualquer que esto fezer que os nossos juizes seculares os possam dello conhocer e ouçam ataa fim e puni-lo, pois que leigo he. E ay mandamos aas nossas justiças que o julguem e a guardem daqui en diante seem outro embargo.

[24 $\left.{ }^{\mathrm{a}}\right]$ Disseram alguuns que, se alguum judeu ou mouro se tornar cristaão e lhe alguum chamar mouro ou judeu ou tornadiço que as justiças ecresiasticas deviam dello de conhecer, o que nos achamos que he o contrairo. Ante achamos, porque todos sam leigos e da nossa juridiçom e que nos devemos delo (fl. 97) de conhocer. E defendemos aaquel a que chamarem mouro ou judeu que se tornou cristaão que nom demamde perante o juiz ecclesiastico mas perante as nossas justiças. E se ho demandar que pague aa quel que o acusar triinta coroas ou o valor que aaquel tempo valerem.

[25 $]$ Se alguum leigo ferir alguum clerigo e o clerigo o quiser demamadar por a enjuria, nos achamos, segundo acordo do nosso comselho, que quanto he ao civil 
e emenda e corregimento que o deve de demamdar peramte as nossas justiças e nom perante os juizes eclesiasticos. E mandamos aos nosso subditos que quando forem demamdados perante os juizes eclesiasticos que nom respondam perante eles sob pena de seerem presos ataa nossa mercee, pera lhes darem pena qual merecerem em tal caso, porque o autor deve de seguir o foro do reeo. Jura vulgaria.

[26 $6^{\mathrm{a}}$ Mandamos que todo-los da nossa terra que trouverem casas ou posisoões d'alguma igreja ou mosteiro arrendadas ou aforadas ou em infitiosim dadas e o tenpo for passado que hera de trager aquela herança, e o clerigo ou a hordem a tomar que, posto que seja citado, que reponda perante a igreja por a pensom ou parte dela, que nom responda perante della, pois que já nom tem coussa de igreja. E o nosso leigo que se o contrairo fezer que seja presso e nom seja solto ataa que pague quorenta dobras ou o seu valor pera aquel que o acusar. E esto achamos per dereito, porquanto a divida que o leigo deve nom sam beens eclesiasticos.

$\left[27^{\mathrm{a}}\right]$ Nos achamos per os outros reis que a clerezia dos nossos regnos, arcebispos, bispos e prellados, e esso medes de hordeens, tam bem d'ordem como de cavalaria, os reis que ante nos forom defemderom que nom podessem guaançar nem herdar nem aver nemhuma coussa nos seus regeengos nem nos seus herdamentos. E que por os seus almoxarifes e recadadores nom recadarem como devyam, lhe forom tomados e enalheados peça dos ditos herdamentos. Por a qual coussa El Rey Dom Denis nosso bisavoo fez com os prellados que entam eram em seu reigno que des huum termo e tempo ataa ca que nemhuum nom podesse guaançar nem aver herdamento nenhuum em seu regeengo e herdamento, e que o d'antes ata aquel tempo que o podessem teer pagando a El Rei aquello que de dereito deviam de pagar. E por estas cousas nos ficarom e ficam muitas demamdas abridas, tan bem das posisoões como das rendas que nos sam devudas e alguuns clerigos dizem que nom am-de responder senom perante seu juiz e porque nos acha (fl. 97v) mos huum artigoo dos quorenta que forom dados per o Padre Santo, em que o Padre Santo da lugar que os clerigos e hordees possam seer demamdados por as coussas dos regeengos e herdamentos em qualquer caso que seja, porem mamdamos aos juizes dos nossos feitos e 
desembargadores e almoxarifes e comtadores que em taaes casos os costrangam de responderem perante elles e dem livramento nos feitos como acharem que he dereito. Et articulus factus im romana curia et approbatus per papam a quo non potest dicedi et casus in vox de foro competenti.

[28 $]$ Comthinuadamente veem leteras do Padre Santo e do Meestre de Rodes e dos desembargadores do santo paço ou d'outrem aa nossa terra por feito de beneficios e d'outras coussas sobre que se husam de dar cartas. E porque os reis que amte nos forom virom que podiam sser maas e contra sua pesoa, e esso medes contra o regno, e esso meesmo poderiam sser sorreticias ou falsas, porende hordenarom que nemhuma carta do Padre Santo que veesse ao regno que nenhuum tabaliam nom fosse tam ousado que a desse a publicaçom nem a execuçom. E porque nos entendemos que aquello por que sse fundarom nossos antecesores a fazer esto que era boom de nos fazer assi por garda de todo-los do regno, assi eclesiasticos como segraaees por nom perderem seu dereito por leteras sorreticias ou por outras muytas coussas que see em esto sooem de fazer, porem mamdamos e poemos por ley que qualquer que esta cousa fezer, e publicar leteras nem executar, a menos que venha aa nossa chamcelaria para se poderem proveer see sam booas e taaes como devem, que qualquer que o contrairo desta coussa fezer, quer seja tabaliom quer outra pessoa, que moira porem e perca os beens que tem pera a coroa do reigno. E mandamos aas nossas justiças que, se alguum fosse tam ousado que sem carta da npssa chamcelaria publicasse taaes cartas, que nom façam per ellas nenhuma obra nem execuçom. Consuetudo dat. Jurdicionem .

$\left[29^{\mathrm{a}}\right]$ Algumas comtendas se sooem a fazer antre os homens da nossa terra por alguma herança ou per algunns outros beens moviis, em esta guissa: huum clerigo vendeo ou deu alguma coussa de raiz ou movel a alguum leigo, em tal guissa que o clerigo lhe deve seer autor dello, e acontece que alguum demamda a coussa que foy vendida ou dada ao leigo e que asi ouve do clerigo e el leigo da por autor o clerigo do que he assi vendeo ou deu. Porem foi duvida se avia de respomder perante nos ou perante os juizes eclesiasticos. E achamos com os do nosso comselho e desembargo que aquel clerigo que asi (fl. 98) he nomeado por autor que deve de responder perante as nossas justiças perante que já o leigo he 
demandado. Porem mamdamos aos nossos juizes e justiças que assi conhoçam em taaes feitos porque per que já o leigo he demamdado. Porem mamdamos aos nossos juizes e justiças que assi conhoçam em taaes feitos porque per deteito assi se deve de gazer. E se o clerigo nom quiser viinr perante elles que requeiram o seu prellado que o costrangua a viinr aly responder. E se ho prellado o nom quiser costranger, mamdamos aos nosos juizes que no-lo façam saber ou ao nosso chanceler pera nos tornarmos a ello por guarda da nossa juridiçom. Est gl. in. c. clericus xj q. 1. Et in 1. si. venditor ff. de vide. E he caso no capitulo si. clericus extra de fo. Compe.

$\left[30^{\mathrm{a}}\right]$ Foy achado per os do nosso comselho per dereito e de sy per husança d'huum artigoo que foi feito em tempo del Rey Dom Denis nosso bisavoo des entam aca que qualquer clerigo que fosse moordomo d'alguum senhor leigo e por sua comta for requerido de a dar, deve-a dar perante o nosso juiz e daquello por que ficar deve-o de costranger o nosso juiz e perante el deve de responder. E porem mamdamos aos nossos juizes que, quando taaes feitos perante eles veerem que tomem delles conhocimento e os desembarguem, nom embargamdo que elle alegue que he clerigo e que há-de seer demamdado perante seu vigairo. Vide c. 2 um de clerici vel mo. Et Ioh. An. in c. I de obli. ad ratioci et per doc. Jur. Cano. Ibidem.

[31 $\left.{ }^{a}\right]$ Ainda foi achado em dereito que, se alguum clerigo d'ordees mayores fosse desolluto seendo goliardo ou filhasse oficio de jograr ou de tiragoiro (?) ou bufam ou outros oficios semelhaaes, e de estes taaes seendo-lhe provado que husou de taaes oficios per huum anno por que de dereito perde todo privilegio clelical, os nossos juizes devem de conhocer de quaaesquer malaficios que fezerem e lhe darem pena, nom embargamdo quaaesquer cartas d'ordees meyores que tenham. Ut in c. clerici de vita et hone. cleri. in sexto et ibi per cano. ad plenum Io. Andree et per alios.

$\left[32^{\mathrm{a}}\right]$ Acontece alguma vez que os reis leixam a alguum clerigo trager alguuns beens tenporaaes seus emquanto sua mercee he e per os beens que assy traz demamdam o dito clerigo. Mamdamos que, emquanto elle trouver taaees beens nossos que elle responda por taaes beens perante os nossos juizes, aos quaaes 
nos mamdamos que os costrangam que respondam perante eles, porquanto a nos perteence em tal casso a juridiçom. In c. solite in titulo de maio. et obe. Et in c. verum de foro competenti.

[33 $]$ Ainda foi achado que, se alguum homem ouvesse alguma demamda em feitos civis seendo leigo e fosse demamdado perante os nossos juizes e depois este tal se tornou clerigo, tal clerigo deve de responder peramte os nossos juizes perante que o feito foi começado. E mandamos aos (fl. 98v) nossos juizes quando taaes feitos perante delles moverem, que tomem dello conhecimento e costrangam os clerigos que respondam perante eles, porquanto em tal caso a nos perteence conhocimento. In c. proposuisti. extra de foro comp. Et in 1. s. quis postea f. de judi. Et in 1. cum quidam puella. Et in 1. pene de jud. omi. Jud.

$\left[34^{\mathrm{a}}\right]$ Acha-se em direito e assy foy achado nos artigoos d'el rey Dom Denis que, se acomtece que alguum clerigo he demandado per alguum leigo perante o bispo ou perante seu vigairo sobre demamda real, e os bispo ou vigairo he negligente a nom fazer dereito, que em tal casso nos podemos conhocer de tal feito e suplir a negridencia do prellado e determinhar do clerigo demamdado. Pero por se saber se o prellado he negrigente deve o prellado ou seu vigairo seer requerido per o nosso juiz que detreminhe dito feito e atempar-lhe huum tempo aguisado a que conhoça e determine o dito feito. E entam mostrando-se sua negrigencia delle, entam o tome o nosso juiz e determinhe como achar que he dereito. Notarum prost. In suma de foro competenti.

[35 $]$ Algumas vezes se acha que alguuns clerigos falsam leteras do Padre Santo e nossas cartas esso mesmo. E porque os direitos mamdam que taaes clerigos devem de seer degradados per seus prellados e dados aa justiça sagral para os punir por os dictos malificios, achamos que, quando a nos he de tall coussa querellado, que nos o devemos de mandar premder E conhocer delle se fez a dita falsidade. E se achado for que a fez e entam entregua-lo ao bispo ou prellado ou a seu vigairo com todo o feito que o degrade e lhe seja logo requerido que no-lo entregue pera del fazermos dereito e justiça. E mamdamos aos nossos juizes e justiças que asy o façam comprir e aguardar. Ut in c. ad falsari extra. de fal. Et eodem titulo ad obedi. 
[36 $6^{\mathrm{a}}$ Muitas vezes acontece que alguum clerigo amda em nossa cassa e demamda outro clerigo que outrossy anda em nossa casa por cousa que nom seja de crime nem da Igreja. Estes taaes devem de seer ouvidos e demamdados perante o nosso corregedor da corte, porque estes taaes sam nosos familiares. E assy se husou em tenpo dos reis que amte nos forom e achado em os artigoos del rei Dom Denis e ainda fundado em rassom porque, se alguuns nossos capelaaes fossem demamadados perante outro juiz fora da nossa corte, estes taaes nom poderiam servir em a nossa capella e nos nom poderiamos delles seer servido em seus oficios. Artigoo he.

(fl.94) $\left[37^{a}\right]$ Item achamos que em este caso os nossos juizes conhocem e podem conhocer dálguuns feitos civiis d'alguuns clerigos, o qual caso he este. No Studo Geerall que esta em este regno nos poemos hi juiz que ouça os feitos dos scollares. E se acontece que alguum clerigo lea naquel studo de soo os lemtes que em elle leem de qualquer siemcia que seja, se for demamdado e el respondera perante o juiz da universidade, assi como el tem de seu privilegio que nom possa seer demamdado senom perante o juiz da universidade. Porem mamdamos que quando tall caso aveer que o nosso juiz da universidade tome conhocimento de tal feito e vaa per el en deante e o livre como achar que he dereito. Extra de foro comp. per explanatorem et in autentica habita C. ne filius pro patre. notatur.

$\left[38^{\mathrm{a}}\right]$ Achamos e muitas vezes acontece que perante as nossas justiças os nossos sogeitos e da nossa juridiçom demamdam suas heranças aaquelles que as traguem ou posuem, propoemdo em suas auçoões que sam lidimos e nacidos de lidimos casamentos e como lidimos devem d'herdar taaes heranças. E da outra parte se poem que nom sam lidimos nem devem d'herdar tal herança porque sam incestuosos ou adulterinos ou outro caso semelhante por que nom devem d'herdar, dizemdo que ao tempo que o seu padre geerou era casado com outra molher e que eram parentes aaquem do quarto graaoo. E porquanto nos achamos em dereito que quando se tal exeiçom pooem incidentemente que nos devemos dello de conhocer, depois que o feito he começado e nom os juizes eccresiasticos. Porem mamdamos aas nossas justiças que quando a tal casso ouver que elas tomem conhocimento de taaes feitos e os nom remetam aos juizes 
eclesiasticos, porquanto em taaes casos he nossa a juridiçom. In 1. tercia per bar. f. matri et in 1. quoc. Et in 1. omi. novatione.

[39'] Muitas vezes acontece que o clerigo d'ordees sagras ou mayores conpromete em o juiz nosso leigo da coussa que nom he eccresiastica ou he demandado e elle comsente e nom declina a jurdiçom, mas comsente ataa sentença deffenetiva, da quall nom apellou nem agravou, o nosso juiz pode executar tal sentença em nos beens do clerigo que assy consentio, pois nom decrinou tal jurdiçom. E porem mamdamos aos nossos juizes e justiças que quando taaes feitos e casos perante elles veerem que dem taaes sentenças aa exucuçom, asi nos beens da igreja como nos seus proprios patrimonyaaes di dito clerigo.

[40 $]$ Huum mouro ou judeu tornou-se cristaão e depois em desprazamento da fe catolica tornou-se judeu ou mouro. Alguuns diziam que em tal casso a jurdiçom pertencia a juridiçom ecresiastica, e nos achamos em dereito que a juridiçom em taaes casos perteence a nos. Porem mamdamos que (fl. 94v) quamdo taaes feitos peramte os nossos juizes e desembarguadores veerem que elles tomem delles conhocimento e o liverm como acharem per dereito.

Forom pobricadas estas lex e hordenaçoões per o doutor Diogo Martinz do Desembargo d'el Rey aos xis dias do mês de Dezembro da sobredita era.

Presemte todo-los desembargadores e ouvidores e sobrejuizes desse senhor, das quaaes hordenaçoões o comcelho e homeens boons da cidade de Lixboa nos pedirom por mercee que lhe mamdassemos dar o trellado dellas em esta carta testemunhavil, porquanto se entendiam por ella ajudar, e nos mamdamos-lha dar.

Dante em a cidade de Lixboa, xiiij dias d'Agosto. El rey o mamdou per Vaasco Steves bacharller em lex seu vassalo e chamceller-mor. Alvaro Anes a fes. Era de mil iiij c e cinquenta e oyto annos ${ }^{45}$.

\footnotetext{
${ }^{45}$ Da era de César, 1420 da era de Cristo. A era de César vigorou em Portugal até que, em carta de 22 de Agosto de 1460, D. João I mandou que se usasse a era de Cristo (1422). Vd. Ordenações Afonsinas, Liv. IV, Tít. LXVI.
} 


\section{FONTES E BIBLIOGRAFIA:}

ALBUQUERQUE, Martim de e ALBUQUERQUE, Ruy de, História do Direito Português, 10ª edição, I Volume (1140-1415), Lisboa, Ed. Pedro Ferreira, 1999.

COELHO, Maria Helena da Cruz, D. João I, Lisboa, Círculo de Leitores, 2005. ISBN: 972-42-3488-6.

COSTA, António Domingues de Sousa, "Leis atentatórias das liberdades eclesiásticas e o papa Martinho V contrário aos Concílios Gerais", in Biblioteca Pontificii Athenaei Antoniani, 19, Studia Historico-Ecclesiastica, Festgabe fur Prof. Luchesuius G. Spattling, O F. M., Roma, Pontificium Athenenaeum Antonianum, 1977, pp. 505-592

Dicionário de História Religiosa de Portugal, (Dir. AZEVEDO, Carlos A. Moreira) 4 Vols., Lisboa, Círculo de Leitores, 2000-2001, Vol. I. ISBN: 972-42-2313-2.

DUARTE, Luís Miguel, D. Duarte, Lisboa, Círculo de Leitores, 2005. ISBN: 97-42$3588-2$.

DUARTE, D., Leal Conselheiro, Actualização ortográfica, introdução e notas de João Morais Barbosa, Lisboa, Imprensa Nacional-Casa da Moeda, 1982.

HOMEM, Armando Luís de Carvalho, O Desembargo Régio (1320-1433), Porto, INIC, 1990.

LOPES, Fernão, Crónica del Rei Dom Joham I de Boa Memoria e dos Reis de Portugal o Décimo, Parte Primeira, Prefácio de Luís F. Lindley Cintra, Lisboa, Imprensa Nacional-Casa da Moeda, 1977.

MARQUES, José, A Arquidiocese de Braga no Séc. XV, Lisboa, Imprensa NacionalCasa da Moeda, 1988.

NASCIMENTO, Aires Augusto Nascimento, "Estratégia diplomática e arte da descrição geográfica numa obra latino-portuguesa do século XV; O Livro de Arautos (a. 1416), in Estudos em Memória do Professor Doutor Mário de Albuquerque, Lisboa, 
Faculdade de Letras da Universidade de Lisboa, Instituto Histórico Infante Dom Henrique, 2009, pp. 23-66. ISBN: 978-989-96184-0-4.

NIETO SORIA, José Manuel, Iglesia y génesis del estado moderno en Castilla (13691480), Madrid, Editorial Complutense, 1993.

NUNES, Eduardo, Álbum de Paleografia Portuguesa, Vol. I, Lisboa, Instituto de Alta Cultura, 1969.

Ordenações del-Rei Dom Duarte, Ed. preparada por Martim de Albuquerque e Eduardo Borges Nunes, Lisboa, Fundação Calouste Gulbenkian, 1988.

Ordenações Afonsinas, Nota de apresentação de Mário Júlio de Almeida Costa e nota textológica de Eduardo Borges Nunes, 5 Vols., Lisboa, Fundação Calouste Gulbenkian, 1984.

PINA, Maria Isabel Pessoa de Castro, Os Lóios em Portugal: origens e primórdios da Congregação dos Cónegos Seculares de São João Evangelista, Dissertação de Doutoramento em História apresentada à Faculdade de Ciências Sociais e Humanas da Universidade Nova de Lisboa, 2011 (ex. policopiado).

SOUSA, Armindo de, As Cortes Medievais Portuguesas (1385-1490), 2 Vols., Porto, INIC, 1990.

VENTURA, Margarida Garcez, "Uma lâmpada de prata e muito mais: testemunhos de D. Duarte sobre a santidade de Nuno Álvares Pereira", in Revista Portuguesa de História do Livro, Ano XIV, Vol. 27 (2011), pp. 243-271. ISSN: 0874-1336.

VENTURA, Margarida Garcez, "Portugal e Castela na reconquista cristã e na partilha do mundo: legitimidades, debates, cedências (1249-1494), Revista Signum - Revista da ABEM on line, 2011, vol. 12, n. 1, pp. 126-146. ISSN: 2177-7306.

VENTURA, Margarida Garcez, D. Duarte, in História dos Reis de Portugal, 2 Vols, Lisboa, QuidNovi / Academia Portuguesa da História, 2010-2011, Vol I, 2010, pp. 491538. ISBN: 978-989-628-204-2. 
VENTURA, Margarida Garcez, O ofício de rei no Portugal quatrocentista. Teoria e práticas de poder", in O Portugal Medieval. Monarquia e Sociedade, Org. NOGUEIRA, Carlos, São Paulo, Alameda, 2010, pp. 125-141. ISBN: 978-85-7939-022-7.

VENTURA, Margarida Garcez, "Elementos para a compreensão da vigilância do rei sobre o seu reino: o beneplácito régio", in Poder Espiritual/Poder Temporal. As relações IgrejaEstado no tempo da monarquia (1179-1909). Actas do Colóquio, Lisboa, Academia Portuguesa da História, 2009, pp. 441-449. ISBN: 978-972-624-180-5

VENTURA, Margarida Garcez, "Lisboa, a cidade do Messias: bem aventuranças e privilégios materiais na dinâmica da Dinastia de Avis", Lisboa - Utopias na Viragem do Milénio, Actas do III Colóquio Temático, Lisboa, Câmara Municipal, s. d. [2001], pp. 461-469. ISBN: 972-8517-27-0.

VENTURA, Margarida Garcez, Igreja e poder no século XV. Dinastia de Avis e Liberdades Eclesiásticas (1385-1450), Lisboa, Edições Colibri, 1997, pp. 32-38.

VENTURA, Margarida Garcez, Poder régio e liberdades eclesiásticas (1385-1450), 2 Vols, Dissertação de Doutoramento em História da Idade Média apresentada à Faculdade de Letras da Universidade de Lisboa, Lisboa, 1993 (ex. policopiado).

VENTURA, Margarida Garcez, O Messias de Lisboa - Um Estudo de Mitologia Política (1383-1415), Prefácio de Martim de Albuquerque, Lisboa, Edições Cosmos, 1992.

VENTURA, Margarida Garcez, "Um novo conceito de Estado, um novo conceito de Igreja. Notas sobre as leis de desamortização de D. Dinis", trabalho apresentado no Congresso Internacional "Dom Dinis. 750 Anos do Seu Nascimento" (Lisboa, Sociedade de Geografia de Lisboa, 2011, no prelo).

ZURARA, Gomes Eanes de, Crónica da Tomada de Ceuta por El Rei D. João I, por Francisco Maria Esteves Pereira, Lisboa, Academia das Ciências, 1915. 


\section{COMO CITAR ESTE ARTIGO}

\section{Referência electrónica:}

VENTURA, Margarida Garcez - “As «Leis Jacobinas». Estudo e transcrição”.

Medievalista [Em linha]. No12, (Julho - Dezembro 2012). [Consultado dd.mm.aaaa].

Disponível em

http://www2.fcsh.unl.pt/iem/medievalista/MEDIEVALISTA12lventura1203.html.

ISSN 1646-740X.

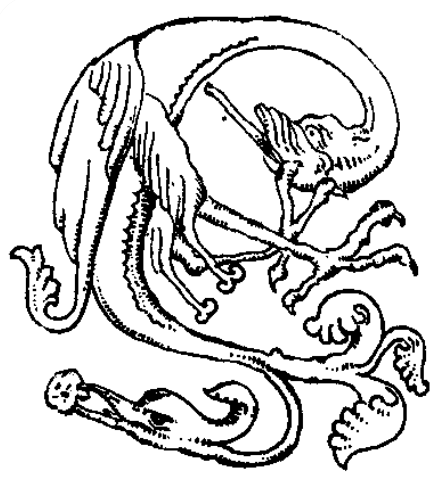

